\title{
Defective insulin secretion in pancreatic $\beta$ cells lacking type 1 IGF receptor
}

\author{
Shouhong Xuan, ${ }^{1}$ Tadahiro Kitamura, ${ }^{2}$ Jun Nakae, ${ }^{2}$ Katerina Politi, ${ }^{1}$ Yoshiaki Kido, ${ }^{2}$ \\ Peter E. Fisher, ${ }^{3}$ Manrico Morroni, ${ }^{4}$ Saverio Cinti, ${ }^{4}$ Morris F. White, ${ }^{5}$ Pedro L. Herrera, ${ }^{6}$ \\ Domenico Accili, ${ }^{2}$ and Argiris Efstratiadis ${ }^{1}$ \\ ${ }^{1}$ Department of Genetics and Development, \\ ${ }^{2}$ Department of Medicine, and \\ ${ }^{3}$ Department of Pathology, College of Physicians \& Surgeons, Columbia University, New York, New York, USA \\ ${ }^{4}$ Department of Anatomy, University of Ancona Medical School, Ancona, Italy \\ ${ }^{5}$ Howard Hughes Medical Institute, and Joslin Diabetes Center, Harvard University, Boston, Massachusetts, USA \\ ${ }^{6}$ Department of Morphology, University of Geneva, Geneva, Switzerland
}

\begin{abstract}
Defective insulin secretion is a feature of type 2 diabetes that results from inadequate compensatory increase of $\beta$ cell mass and impaired glucose-dependent insulin release. $\beta$ cell proliferation and secretion are thought to be regulated by signaling through receptor tyrosine kinases. In this regard, we sought to examine the potential proliferative and/or antiapoptotic role of IGFs in $\beta$ cells by tissuespecific conditional mutagenesis ablating type 1 IGF receptor (IGF1R) signaling. Unexpectedly, lack of functional IGF1R did not affect $\beta$ cell mass, but resulted in age-dependent impairment of glucose tolerance, associated with a decrease of glucose- and arginine-dependent insulin release. These observations reveal a requirement of IGF1R-mediated signaling for insulin secretion.
\end{abstract}

J. Clin. Invest. 110:1011-1019 (2002). doi:10.1172/JCI200215276.

\section{Introduction}

The ability of pancreatic $\beta$ cells to synthesize, store, and release insulin in response to variations in circulating metabolite levels and intracellular glucose metabolism is regulated by changes in ATP/ADP ratios resulting in $\mathrm{Ca}^{2+}$ mobilization (1). Alterations of this sensing loop occur early in the pathogenesis of type 2 diabetes, but are initially compensated by an increase of $\beta$ cell mass (2). In this respect, pancreatic $\beta$ cells appear to differ from other terminally differentiated cell types by retaining their ability to proliferate, as demonstrated in both physiological conditions (growth, gestation) and disease states (obesity, insulin resistance) (3). In addition to presumptive proliferation of existing $\beta$ cells, there is evidence for $\beta$ cell neogenesis from undifferentiated progenitors, apparently arising from the epithelial lining of pancreatic ducts (4-8).

The factors inducing $\beta$ cell proliferation under normal or pathological conditions are largely unknown, although some evidence exists about the involvement of FGFs (9), HGFs (10), and placental lactogen (11). Moreover, signaling by receptor tyrosine kinases has

Received for publication February 2, 2002, and accepted in revised form August 9, 2002.

Address correspondence to: Domenico Accili, Berrie Research Pavilion, 1150 Saint Nicholas Avenue Room 238, New York, New York 10032, USA. Phone: (212) 851-5332; Fax (212) 851-5331; E-mail: da230@columbia.edu.

Conflict of interest: No conflict of interest has been declared. Nonstandard abbreviations used: phosphoinositide 3-kinase (PI 3-kinase); insulin receptor substrate (IRS); type 1 IGF receptor (IGF1R); insulin receptor (IR); 5-bromo-2-deoxyuridine (BrdU); embryonic day (E). been implicated as a regulatory mechanism in both $\beta$ cell proliferation (12-14) and insulin release $(9,15-19)$. In particular, insulin/IGF signaling through insulin receptor substrate (IRS) and phosphoinositide 3-kinase (PI 3-kinase) appears to regulate several aspects of $\beta$ cell function. Thus, ablation of the insulin/IGF receptor substrate IRS- 2 impairs $\beta$ cell proliferation $(20,21)$, whereas ablation of $\mathrm{p} 70^{\mathrm{s} 6 \mathrm{k} 1}$, an Akt substrate, is associated with a decrease in $\beta$ cell size (22). Conversely, overexpression of a constitutively active mutant Akt 1 increases $\beta$ cell mass and protects from streptozotocininduced diabetes $(23,24)$. However, mutations affecting the components of the IRS- $2 \rightarrow A k t \rightarrow p 70^{s k k 1}$ axis do not perturb glucose sensing or insulin production. In contrast, mutations of Insulin receptor (Ir) (25) or Irs1 (26) impair insulin synthesis and secretion mediated by PI 3-kinase-dependent pathways $(17,19,26)$. These observations suggest that signals regulating $\beta$ cell proliferation and insulin secretion diverge downstream of PI 3-kinase; i.e., Akt is not the sole effector of PI 3-kinase. Nevertheless, the role of growth factor signaling through PI 3-kinase as related to insulin secretion remains poorly understood. Additional difficulties arise because, against expectation, knockout of the gene encoding the p85 $\alpha$ subunit of PI 3-kinase results in increased insulin secretion (27), consistent with studies using PI 3-kinase inhibitors (28). Because of the known relationship between IGF and PI 3-kinase signaling and results indicating that IGFs inhibit insulin secretion (29-31), we sought to examine in mutant mice the contribution of type 1 IGF receptor (IGF1R) function to insulin secretion and $\beta$ cell proliferation, which could differ from that of the IR pathway. 
Although the roles of IGFs in $\beta$ cells have not been completely elucidated, these ligands and their cognate receptors are both expressed in this tissue (32-35). Interestingly, the developmental wave of $\beta$ cell apoptosis observed in neonatal rats (36) is associated with a decrease in IGF-2 expression $(32,37)$, leading to the suggestion that the IGFs have an antiapoptotic function in $\beta$ cells. On the other hand, overexpression of IGF- 2 in $\beta$ cells (38), but not in liver $(39,40)$, results in diabetes, presumably through increased insulin production with concomitant downregulation of insulin sensitivity.

A potential role for IGF1R acting as a mediator of $\beta$ cell proliferation through IRS- 2 has been implied by observations indicating that the $\beta$ cell failure observed in Irs $2^{-/-}$mice is exacerbated by IgfIr haploinsufficiency (13). However, generalized lack of IGF1R is lethal in the immediate postnatal period (41), thus precluding an extensive analysis of the role of IGF signaling in $\beta$ cell physiology. To circumvent this limitation and analyze the role of IGF1R in $\beta$ cells, we have used conditional mutagenesis with the cre/loxP site-specific recombination system to generate mice lacking IGF1R specifically in pancreatic $\beta$ cells. Here we show that these mutant mice are glucose intolerant and exhibit an insulin secretion defect.

\section{Methods}

Mice. Animals carrying a floxed Igfl $r$ allele (Igf1rlox) (42) or a null Igf1r allele $\left(I g f 1 r^{+/-}\right)(41)$ and transgenic mice expressing the Cre recombinase under the transcriptional control of the rat insulin-2 promoter (InsPr-Cre) (43) have been described previously. A mating program with $I g f 1 r^{+/}, I g f 1 r^{l o x /+}$, and InsPr-Cre mice was used to generate progeny of five genotypes: Igf1r $r^{+/}, \operatorname{Igf} 1 r^{l o x /+}$, Igf1r $r^{l o x /-}, \operatorname{Igf1} r^{\Delta l o x /-}$, and $I g f 1 r^{\Delta l o x /+}$ (in which exon 3 sequences have been deleted as a result of Cre-mediated recombination). PCR analysis was used for genotyping. The wild-type, null, and Igf1 $r^{l o x}$ alleles were detected with primer $5^{\prime}$ CTTCCCAGCTTGCTACTCTAGG 3' (P1, forward, located upstream of the second loxP site) and 5' CAGGCTTGCAATGAGACATGGG 3' (P2, reverse, located downstream of the same loxP site) (Figure 1). The Igf1r $r^{\Delta l o x}$ allele was detected using a different forward primer, $5^{\prime}$ TGAGACGTAGCGAGATTGCTGTA 3', located $5^{\prime}$ of the loxP site in intron 2 (P3 in Figure 1), and the reverse primer, $\mathrm{P} 2$. The products of the three alleles were $120 \mathrm{bp}$ (wild-type or null allele), $220 \mathrm{bp}$ (Igf1 $\left.r^{l o x}\right)$, and $320 \mathrm{bp}\left(\operatorname{Igf} 1 r^{\Delta l o x}\right)$. PCR amplification conditions were 30 cycles at $94^{\circ} \mathrm{C}$ for 45 seconds, $61^{\circ} \mathrm{C}$ for $45 \mathrm{sec}$ onds, and $72^{\circ} \mathrm{C}$ for 1 minute.

$A b$ 's and Western blot analysis. An antipeptide antiserum against the carboxy-terminal domain of the IGF1R protein (C20; Santa Cruz Biotechnology Inc., Santa Cruz, California, USA) was used for Western blot analysis as described previously (44). Anti-tubulin antiserum was from Covance (Richmond, Virginia, USA). We employed a Triton extraction buffer for protein isolation and standard methods for Western blot analysis. The intensity of the bands on the autoradiogram was quantified using a Kodak Image Station C400 image analyzer for chemiluminescence.

Phenotypic analysis. Only male mice were used in the analysis, since they are more prone to insulin resistance. Blood glucose levels were determined using an Accucheck glucometer (Boehringer Mannheim GmbH, Mannheim, Germany). Serum insulin was measured by a radioimmunoassay using a rat insulin standard (Linco Research Inc., St. Charles, Missouri, USA). All assays were carried out in duplicate (45).

Intraperitoneal glucose tolerance test. Mice were fasted for 16 hours and then anesthetized. Blood was drawn immediately before and 30,60, 90, and 120 minutes after intraperitoneal injection of glucose $(2 \mathrm{~g} / \mathrm{kg}$ body weight), and then glucose and insulin levels were determined (45).

Insulin secretion assays. Islets were purified from 6month-old Igfl $r^{l o x /+}$, Igf $1 r^{l o x /}$, and Igfl $1 r^{\Delta l o x /}$ mice by collagenase digestion followed by centrifugation over a Histopaque gradient as described previously (46). For insulin-release experiments, islets were manually picked, incubated in Krebs buffer, and stimulated with varying concentrations of glucose or arginine for 1 hour at $37^{\circ} \mathrm{C}$. At the end of the incubation, islets were collected by centrifugation, and the supernatant was assayed for insulin content by radioimmunoassay (46). The cell pellet was assayed for insulin and DNA content to normalize insulin secretion by islet mass.

Immunohistochemical and morphometric analyses. Pancreata were removed from embryonic day 18.5 (E18.5), postnatal day 10 (P10), P30, and P120 Igf1rlox/-, $\operatorname{Igf} 1 r^{\Delta l o x /+}$, and Igf1r $1 r^{\Delta l o x /}$ mice, weighed, and fixed overnight in $4 \%$ paraformaldehyde. Four-micrometerthick sections were immunostained for $\beta$ cells using mouse anti-insulin Ab's or rabbit anti-GLUT-2 polyclonal Ab (Research Diagnostics, Flanders, New Jersey, USA) and for $\alpha$ cells using mouse anti-glucagon Ab's (Sigma-Aldrich, St. Louis, Missouri, USA). For immunohistochemistry with anti-GLUT-2 antiserum (Research Diagnostics), pancreata were fixed in Z-fix and incubated at a 1:300 dilution. Immunoreactivity was detected with the ABC system (DAKO Corp., Carpinteria, California, USA). For morphometric analysis of $\beta$ cell mass, two animals of each genotype were analyzed. For each pancreas, three sections spaced at least $40-\mu \mathrm{m}$ (E18.5 and P10) and $160-\mu \mathrm{m}$ apart (P30 and P120) were covered systematically by accumulating images from nonoverlapping fields that were captured with a digital camera (Nikon 950) and analyzed using the NIH Image 1.60 software (Bethesda, Maryland, USA), as described (45). Results were expressed as percentage of the total surveyed pancreatic area occupied by $\alpha$ and $\beta$ cells. $\beta$ cell mass was calculated by multiplying $\beta$ cell area by pancreatic weight. $\beta$ cell size was calculated from the same sections using a reference standard.

Detection and quantitation of $\beta$ cell replication. Cellular proliferation was evaluated using immunohistochemistry with three markers: the cell cycle antigen Ki67 (NCL-Ki 67p; Castra, Newcastle upon Tyne, United 
a

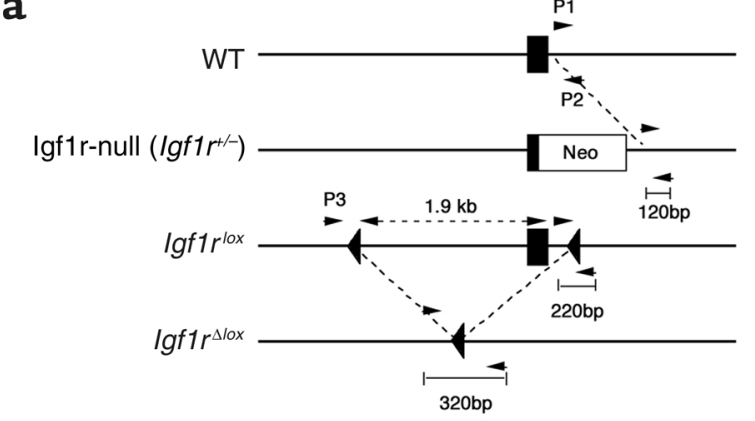

b

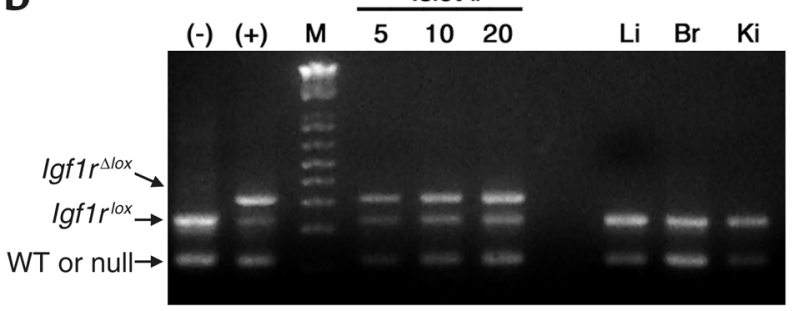

c

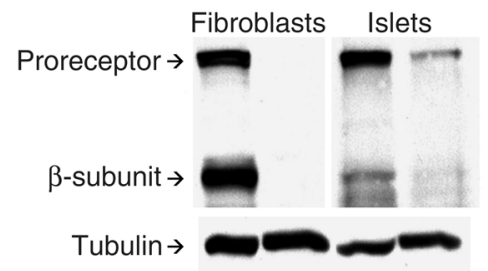

WT $\lg 11 r^{-1}$ WT $\operatorname{lgf1} 1 r^{\Delta 10 x-}$

Kingdom), phosphorylated histone H3 (Upstate Biotechnology Inc., Lake Placid, New York, USA), and 5-bromo-2-deoxyuridine (BrdU; Sigma-Aldrich). For these experiments, pancreata were obtained from E18.5, P10, P30, and P120 Igf1r $r^{l o x /+}, \operatorname{Igf} 1 r^{l o x /-}, \operatorname{Igf} r^{\Delta l o x /+}$, and Igfl $1 r^{\Delta l o x /-}$ mice. BrdU was injected intraperitoneally $(0.1$ $\mathrm{gm} / \mathrm{kg}) 2$ hours before sacrifice into mothers at day 18.5 of pregnancy or P10, P20, and P30 Igf1r $r^{l o x /+}$, Igf1 $r^{l o x /-}$, $\operatorname{Igf} 1 r^{\Delta l o x /+}$, and $I g f 1 r^{\Delta l o x /-}$ mice. For double-staining with anti-BrdU or anti-Ki67 and anti-insulin Ab's, guinea pig anti-insulin $\mathrm{Ab}$ was used. Quantitation of $\beta$ cell replication was performed by counting Ki67-positive cells in three to five sections spaced more than $40 \mu \mathrm{m}$ (E18.5 and P10) or $160 \mu \mathrm{m}$ apart (P30 and P120) in each pancreas. The mean value of Ki67-positive cells was multiplied by $\beta$ cell mass as calculated above to obtain an arbitrary Ki67 labeling index. Apoptosis was measured

\section{Figure 1}

Generation of a conditional IGF1R knockout in $\beta$ cells. (a) A diagram of the Iff1 $r$ locus around exon 3 (filled square) is shown, followed by diagrams of the null $\left(I g f 1 r^{+/-}\right)(41)$, floxed $\left(\lg f 1 r^{l o x}\right)(42)$, and recombined floxed (Igf1 $\left.r^{\Delta l o x}\right)(42)$ alleles. The positions of the P1, P2, and P3 primers (arrows) used for genotyping are indicated. (b) PCR analyses using DNA from islets and control tissues. The lanes labeled - and + correspond to the negative and positive controls. Primers P1 and $\mathrm{P} 2$ yield a product of approximately $120 \mathrm{bp}$ in WT and null Iff $1 \mathrm{r}$ alleles, and $220 \mathrm{bp}$ in the $\lg f 1 r^{l o x}$ allele. In the $\lg f 1 r^{\Delta l o x}$ allele, excision of exon 3 enables amplification to occur between primers P3 and P2, yielding $320 \mathrm{bp}$. In the lanes to the right of the markers, DNA from different tissues of $/ g f 1 r^{\Delta / o x /}$ - mice was used. $\mathrm{Br}$, brain; Li, liver; and Ki, kidney. (c) Western blot analysis of IGF1R expression. We obtained protein extracts from wild-type mouse embryonic fibroblasts or from fibroblasts derived from $/ g f 1 r^{-1}$ mice as positive and negative controls (first two lanes on the left). We purified islets from wild-type (third lane from the left) and $\lg f 1 r^{\Delta l o x /}$ mice (right lane). Following detection of IGF1R, the blot was stripped and reprobed with anti-tubulin antiserum. The position of the various bands is indicated on the left of the autoradiogram.

using the ApopTag peroxidase in situ apoptosis detection kit (S7101; Intergen Co., Purchase, New York, USA) in sections derived from P10, P30, and P120 mice.

Electron microscopy. Two wild-type and two mutant pancreata were fixed in a solution containing $2 \%$ glutaraldehyde, $2 \%$ paraformaldehyde in $0.1 \mathrm{M}$ phosphate buffer, $\mathrm{pH} 7.4$, for 4 hours at $4^{\circ} \mathrm{C}$, post-fixed in $1 \%$ osmium tetroxide, dehydrated in ethanol, and embedded in an Epon-Araldite mixture (Multilab Supplies, Fetcham, United Kingdom). Thin sections were obtained with a MT-X ultratome (RMC, Tucson, Arizona, USA), stained with lead citrate, and examined with a CM10 transmission electron microscope (Phillips, Eindhoven, The Netherlands). We examined three islets in each of the two wild-type mice and three or four islets in the two mutant mice. We obtained serial photos at $\times 1,900$ magnification for each islet section and reconstructed the whole islet at a final enlargement of $\times 4,275$. The specimens were examined blindly and independently by two electron microscopists, who analyzed a total of 448 cells in wild-type and 638 cells in mutant mice.

$m R N A$ quantitation by real-time PCR. PolyA ${ }^{+}$-enriched RNA was isolated from purified islets of $I g f 1 r^{l o x} /+$, Igfl $1 r^{l o x /} /$, and $I g f 1 r^{\Delta l o x /-}$ mice using Micro Fast Track (Invitrogen Corp., Carlsbad, California, USA). Real-time

Table 1

Metabolic parameters

\begin{tabular}{|c|c|c|c|c|c|c|c|c|}
\hline \multirow[t]{2}{*}{ Genotype } & \multicolumn{2}{|c|}{ P0.5 } & \multicolumn{2}{|c|}{9 months } & \multicolumn{4}{|c|}{12 months } \\
\hline & Insulin & Glucose & Insulin (fast) & Glucose (fast) & Insulin (fast) & Insulin (fed) & Glucose (fast) & Glucose (fed) \\
\hline $\lg f 1 r^{\operatorname{lox} /+}$ & ND & ND & $0.56(1)$ & $139 \pm 40(3)$ & $0.8 \pm 0.4(7)$ & $3.0 \pm 0.9(7)$ & $102 \pm 13(7)$ & $127 \pm 7(7)$ \\
\hline $\lg f 1 r^{+/-}$ & nd & ND & $0.7 \pm 0.2(12)$ & $100 \pm 5(12)$ & ND & $2.5 \pm 1.2(10)$ & ND & $128 \pm 32(10)$ \\
\hline $\lg f 1 r^{\operatorname{lox} /-}$ & ND & ND & $0.43 \pm 0.1(2)$ & $122 \pm 16(4)$ & $0.5 \pm 0.3(2)$ & $2.1 \pm 0.8(2)$ & $134 \pm 14(2)$ & $100 \pm 28(2)$ \\
\hline $\lg f 1 r^{\Delta / o x /+}$ & $1.2 \pm 0.2(3)$ & $77 \pm 5(3)$ & ND & $85 \pm 8(3)$ & $0.4 \pm 0.1(2)$ & $1.7 \pm 0.5(2)$ & $104 \pm 20(2)$ & $124 \pm 3(2)$ \\
\hline $\lg f 1 r^{\Delta / o x /-}$ & $1.1 \pm 0.3$ & $75 \pm 6(3)$ & $0.77 \pm 0.3(3)$ & $105 \pm 13(7)$ & $3.3 \pm 1.6(11)$ & $2.9 \pm 0.6(11)$ & $118 \pm 10(11)$ & $130 \pm 6(11)$ \\
\hline
\end{tabular}

The number of animals used for each genotype is shown in parenthesis. The higher insulin levels in 12 -month-old $/ g f 1 r^{\Delta / o x /-}$ mice do not reach statistical significance due to large variation. ND, not determined. 


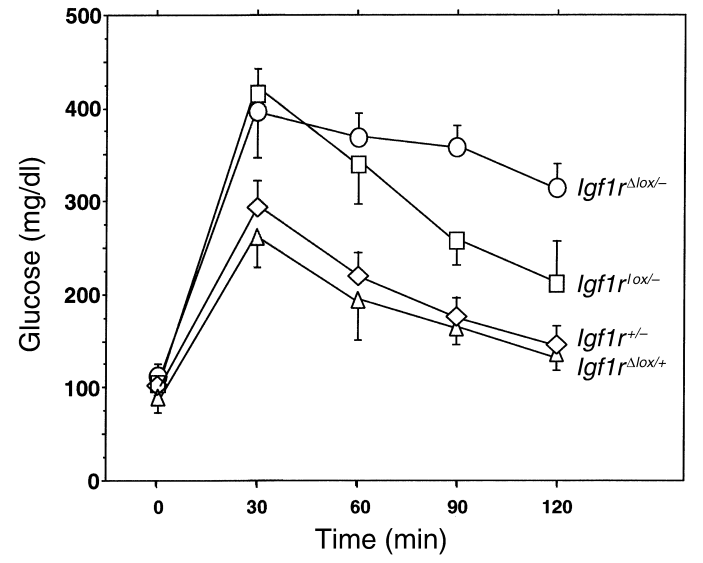

Figure 2

Intraperitoneal glucose tolerance tests in mice lacking IGF1R in $\beta$ cells. Tests were performed in overnight-fasted mice as indicated in Methods. The difference between $\lg f 1 r^{\Delta / 0 x /-}$ and $\lg f 1 r^{\Delta / o x /+}$ is significant at all time points except 0 . The difference between $\lg f 1 r^{\Delta / o x /-}$ and Igf1 $r^{\text {lox } /-}$ is statistically significant at times 90 and 120 . The difference between $\mid g f 1 r^{\Delta / o x /+}$ and $\lg f 1 r^{\mid 0 x /-}$ is statistically significant at times 30 , 60 , and $90(P<0.05$ by ANOVA $)$. Bars represent SEM.

PCR using RNA pooled from three animals per specimen was performed using a Roche Light Cycler PCR instrument and Light-Cycler RT-PCR kit (Roche PerkinElmer, Foster City, California, USA). Each reaction was carried out in triplicate.

Microarray analysis. RNA was extracted from islets using the RNeasy Total RNA Isolation Kit (QIAGEN Inc., Valencia, California, USA), precipitated, and quantified by agarose gel electrophoresis using an aliquot. Five micrograms of RNA was used to synthesize doublestranded cDNA (Invitrogen Corp. kit) using a T7 (dT) ${ }_{24}$ primer (Invitrogen, Carlsbad, California, USA) containing a T7 RNA polymerase initiation site. Biotinylated cRNA was synthesized from the cDNA template using the BioArray High Yield RNA Transcript Labeling Kit (ENZO Diagnostics, Armingdale, New York, USA) and purified with the RNeasy Total RNA Isolation Kit (RNA clean-up protocol; QIAGEN Inc.). After fragmentation in $40 \mathrm{mM}$ Tris-acetate, $\mathrm{pH}$ 8.1, $100 \mathrm{mM}$ KOAc, and 30 $\mathrm{mM} \mathrm{MgOAc}, 15 \mu \mathrm{g}$ fragmented cRNA was hybridized to the MGU74Av2 oligonucleotide microarray (Affymetrix, Santa Clara, California, USA) representative of approximately 12,000 genes. The microarrays were scanned (Affymetrix Scanner), and expression values for the genes were determined using Affymetrix Microarray Suite Version 5.0 and subjected to computer analysis (47).

Statistical analysis. Descriptive statistics, $t$ test for paired data, Kruskal-Wallis test, and ANOVA were performed using the Statsview software.

\section{Results}

Generation of mice lacking IGF1R in $\beta$ cells. Tissue-specific conditional mutagenesis requires crosses between Creproducing and Cre-responding strains of mice. For Cre expression in pancreatic $\beta$ cells of producer mice we used an InsPr-Cre transgenic line, in which Cre transcription is driven by the rat insulin- 2 gene promoter (43). These mice express Cre in $\beta$ cells as early as embryonic day 11.5 (E11.5), and show very limited extrapancreatic expression in the amygdala (P. Herrera, unpublished observations). As responder mice we used previously described compound heterozygotes (42) derived from matings between heterozygotes carrying an Igf1r null allele (IgfIr $\left.r^{+/}\right)$and IgfIrlox/+ conditional mutants carrying a modified Ifflr locus in which exon 3 of the gene is flanked by loxP sites ("floxed"). PCR analysis of DNA extracted from various tissues of progeny carrying the InsPr-Cre transgene and possessing an Igf1 $r^{l o x /+}$ genotype showed that DNA excision leaving behind a single lox $\mathrm{P}$ site had occurred specifically in pancreatic islets (Figure 1a). Additional Southern blot analysis of DNA from several other tissues from which adequate amounts of DNA could be extracted indicated the presence of an exclusively unrecombined allele (data not shown). The extent of recombination detect-

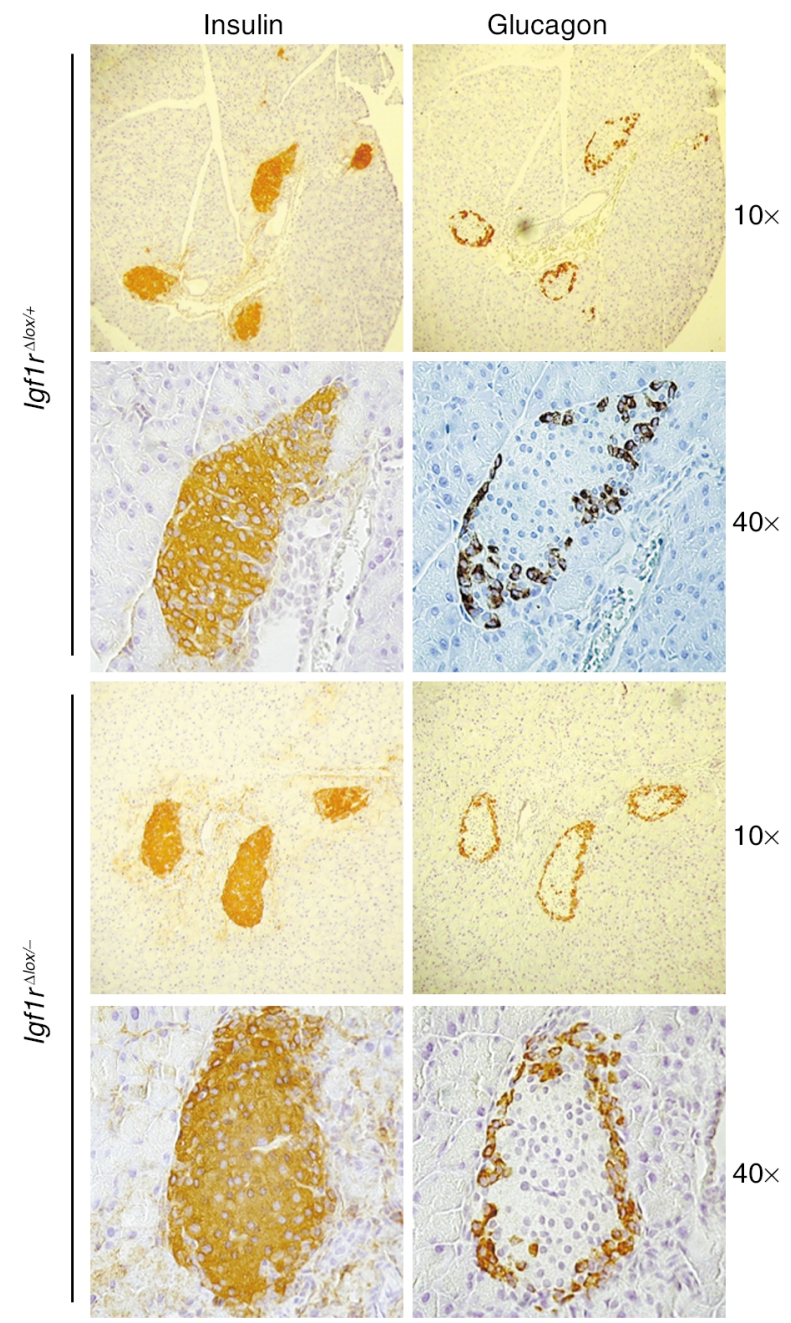

Figure 3

Islet morphology in mice lacking IGF1R in $\beta$ cells. Examples of pancreatic sections from P30 mice of the indicated genotypes that were stained with anti-insulin and anti-glucagon Ab's are shown. 
Table 2

$\beta$ cell mass and size

\begin{tabular}{lccc}
\hline Genotype $(n)$ & $\begin{array}{c}\text { E18.5 } \\
\beta \text { cell mass } \\
(\mu \mathrm{g} / \text { pancreas })\end{array}$ & $\begin{array}{c}\beta \text { cell mass } \\
(\mu \mathrm{g} / \text { pancreas })\end{array}$ & $\begin{array}{c}\text { P30 cell diameter } \\
(\mu \mathrm{m})\end{array}$ \\
$\lg f 1 r^{\operatorname{lox} /+}$ & $7.8 \pm 1.2(2)$ & $\mathrm{ND}$ & $\mathrm{ND}$ \\
$\lg f 1 r^{\mid 0 x /-}$ & $\mathrm{ND}$ & $\mathrm{ND}$ & $\mathrm{ND}$ \\
$\lg f 1 r^{\Delta / 0 x /+}$ & $\mathrm{ND}$ & $637 \pm 160(2)$ & $9.73 \pm 1.15(21)$ \\
$\lg f 1 r^{\Delta / 0 x /-}$ & $7.2 \pm 0.5(2)$ & $705 \pm 102(2)$ & $10.02 \pm 1.74(36)$
\end{tabular}

ed in islets was approximately $80 \%$, consistent with the ratio of $\beta /$ non- $\beta$ ( $\alpha, \delta, P P$, vascular, and connective) cells in normal islets (Figure 1b). Western blot analysis of pancreatic islets with anti-IGF1R antiserum confirmed that the levels of proreceptor and mature $\beta$ subunit were reduced by $85 \%$ in $I g f 1 r^{\Delta l o x /-}$ mice, consistent with ablation of the protein product exclusively in $\beta$ cells (Figure 1c). Parallel immunohistochemical analysis yielded consistent results (data not shown). Igfl $r^{\Delta l o x /}$ mice were born at the expected Mendelian frequency and did not exhibit abnormalities.

Phenotypic characterization of mice lacking IGF1R in $\beta$ cells. To assess the consequences of IGF1R ablation in $\beta$ cells on glucose metabolism, we measured glucose and insulin levels in neonates and adult mice in the fasting and fed states at various ages. No differences were detected between mice with $\operatorname{Ig} f 1 r^{+/-}, \operatorname{Ig} f 1 r^{l o x /+}, \operatorname{Ig} f 1 r^{l o x} /-$, Igf1 $r^{\Delta l o x /+}$, and Igf1 $r^{\Delta l o x /-}$ genotypes (Table 1). Glucose tolerance tests were then performed in adult (6-monthold) mice to assess potential metabolic defects not resulting in overt diabetes. In Igfl $r^{+/-}$and $I g f 1 r^{\Delta l o x /+}$ mice, glucose values rose to approximately $250 \mathrm{mg} / \mathrm{dl} 30 \mathrm{~min}$ utes after intraperitoneal glucose administration and returned to nearly normal values by 2 hours. In contrast, in $I g f 1 r^{\Delta l o x /-}$ mice glucose values rose to approximately $400 \mathrm{mg} / \mathrm{dl}$ and did not decrease appreciably thereafter, consistent with impaired glucose disposal. Iff $1 r^{l o x /} /-$ mice had similar 30-minute glucose values as Igf1 $1 r^{\Delta l o x /-}$ mice, but gradually returned to nearly normal values (Figure 2 ). These data could be interpreted as indicating that the combination of a single null allele and a floxed allele results in haploinsufficiency for Igf $1 \mathrm{r}$ and causes a mild impairment of glucose tolerance. The impairment of glucose tolerance in $I g f 1 r^{l o x /}$ and $I g f 1 r^{\Delta l o x /}$ mice is apparently not due to insulin resistance, since insulin tolerance tests failed to demonstrate differences between the two genotypes and wild-type mice (data not shown). We next examined the consequences of ablation of IGF1R function on pancreatic morphology. Immunohistochemical analysis of pancreata from $I g f 1 r^{\Delta l o x /-}$ mice showed that the islet architecture was normal (Figure 3). Thus, $\beta$ cell mass was similar in all genotypes examined at various time points, as was mean $\beta$ cell diameter (Table 2). In addition, the pattern of expression of the $\beta$ cell-restricted transcription factor Pdx1, as assessed by immunohistochemistry, was similar (data not shown). In contrast, real-time PCR analysis of the expression levels of mRNA encoding the $\beta$ cell glucose transporter
GLUT-2 demonstrated a significant decrease in the islets of $I g f 1 r^{\Delta l o x /-}$ mice (by approximately $40 \%$ ) when compared with $I g f 1 r^{l o x / 4}$ and Igflr $r^{l o x /}$ mice (Figure 4a). Immunostaining of pancreatic sections with anti-GLUT-2 antiserum showed decreased immunoreactivity in $\operatorname{Ig}\left(r^{\Delta l o x /}\right.$ mice (Figure $4 \mathrm{~b}$ ). To determine whether the lack of IGF1R affects $\beta$ cell proliferation, we measured the number of Ki67-positive $\beta$ cells in Igf1 $r^{l o x /-}, \operatorname{Igf} 1 r^{\Delta l o x /+}$, and Igf $1 r^{\Delta l o x /-}$ mice at various ages as an index of mitotic activity. The use of Ki67 for this purpose was validated by staining adjacent sections with two additional proliferation markers, phosphohistone $\mathrm{H} 3$ and BrdU, and then analyzing the correlation between the values obtained with different methods. As shown in Figure 5, phosphohistone H3- and BrdU-positive cells showed a highly significant positive correlation with Ki67-positive cells $\left(r^{2}>0.8, P<0.0001\right)$. Thus, Ki67 was employed for all subsequent analyses. A developmental analysis showed that the number of $\beta$ cells undergoing replication decreased sharply with age.

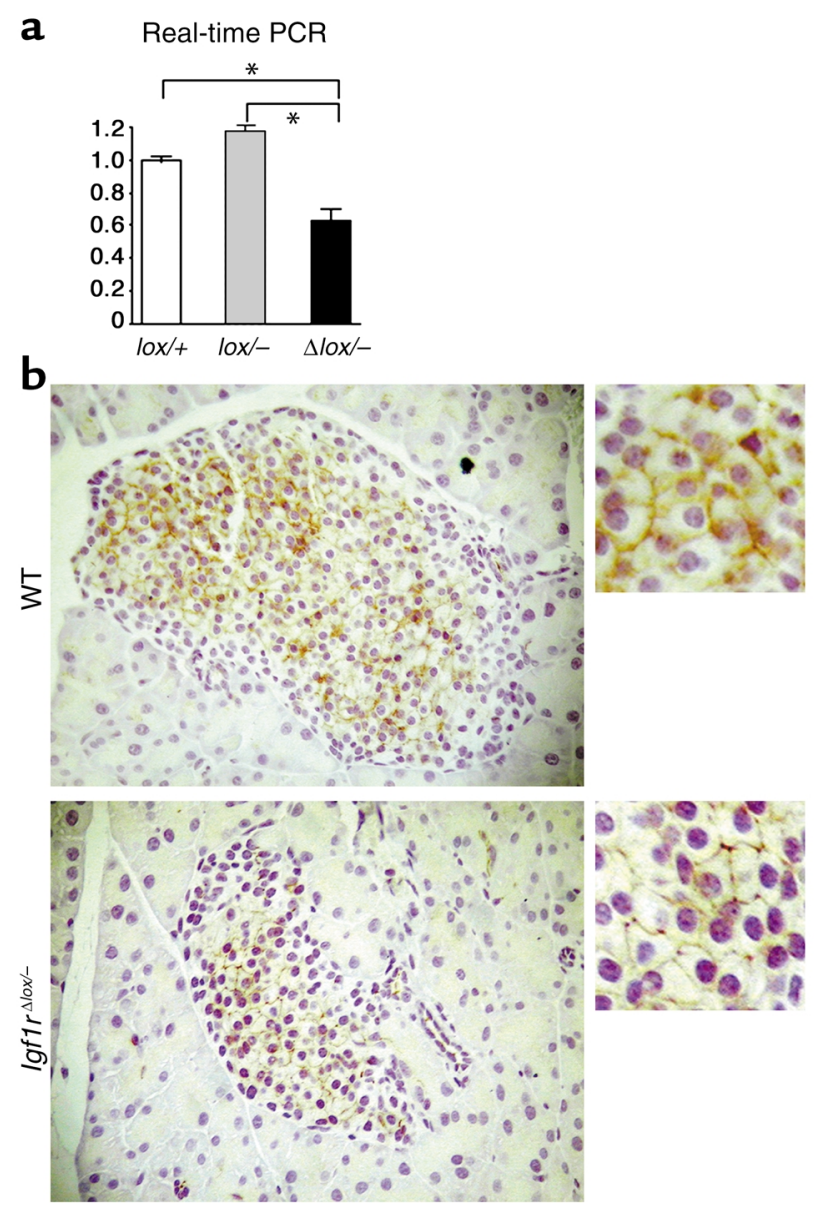

Figure 4

Analysis of Glut-2 expression. (a) Real-time PCR amplification. mRNA was isolated from $\lg 11 r^{\Delta / 0 x /-}$, $\lg f 1 r^{\operatorname{lox} /-}$, and $\lg f 1 r^{\Delta / 0 x /+}$ mice $(n=3$ each; equal amounts were pooled). Amplification was performed using a one-step RT-PCR reaction. The amount of RNA in the reaction was normalized using $\beta$-actin RNA as a control. ${ }^{*} P<0.05$ by ANOVA. (b) Immunohistochemistry with anti-GLUT-2 antiserum. Representative sections of $\lg f 1 r^{\Delta / o x /+}$ and wild-type mice are shown. 


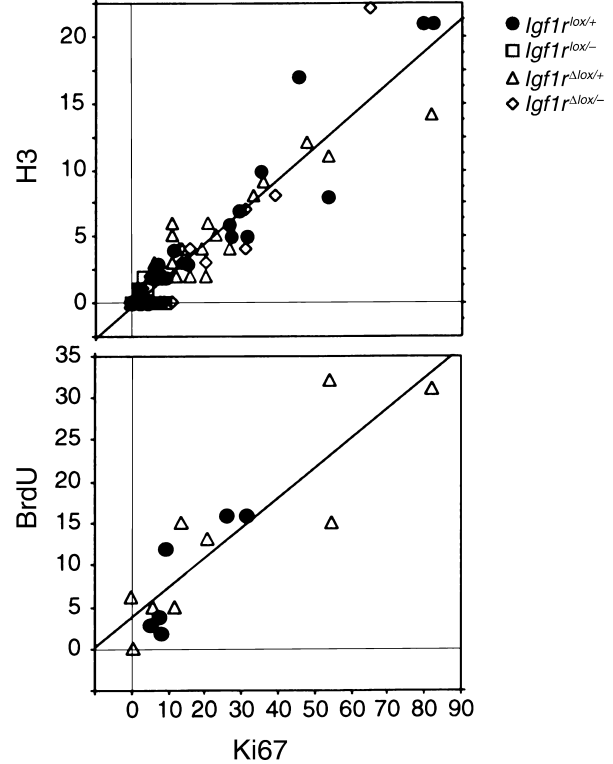

Figure 5

Ki67, histone $\mathrm{H} 3$, and BrdU labeling of $\beta$ cells. Adjacent $4-\mu$ m-thick pancreatic section from mice at E18.5, P10, P30, and P120 were costained with anti-insulin Ab's (to identify $\beta$ cells) and anti-Ki67, or anti-histone $\mathrm{H} 3$ or anti-BrdU Ab's (to provide an index of proliferation). Positive cells were visually scored, and the number of Ki67-positive cells was plotted as a function of the number of histone $\mathrm{H} 3$-positive (upper panel) or BrdU-positive cells (lower panel). Regression analysis was performed using the Statsview software. $r^{2}=0.9$ for the $\mathrm{H} 3 / \mathrm{Ki} 67$ and 0.9 for the BrdU/Ki67 correlation $(P<0.0001)$.

However, no differences were detected between the various genotypes under study (Figure 6). These data indicate that lack of IGF1R does not impair $\beta$ cell replication. Similarly, we observed no differences in the levels of apoptotis ascertained at P10, P20, and P30 using TUNEL staining, although the small number of detectable apoptotic cells did not permit accurate quantitation (data not shown).

Measurements of insulin secretion in purified islets. To examine whether the conditional mutation under study affects insulin secretion, we purified islets from $I g f 1 r^{l o x} /+$, Igfl $1 r^{\Delta l o x /+}$, and Igf1r $\Delta r^{\Delta l o x /-}$ mice, which were incubated in the presence of glucose or arginine. As shown in Figure $7 \mathrm{a}$, glucose induced a dose-dependent increase in insulin secretion up to a maximum of 15 - to 20 -fold over the basal level in islets from $I g f 1 r^{l o x /+}$ and $I g f 1 r^{\Delta l o x /+}$ controls. In $I g f 1 r^{\Delta l o x /-}$ mutants, glucose-induced insulin secretion was also normal at low glucose concentrations, but decreased by approximately $70 \%$ at high concentrations $(P<0.05$ by ANOVA). A similar pattern of response was observed in arginine-induced insulin secretion in Igfl $r^{\Delta l o x /-}$ mutant mice (Figure $7 \mathrm{~b}$ ). On the other hand, the islet insulin content was similar in the $\operatorname{Ig} f r^{l o x} /+$, $I g f 1 r^{\Delta l o x /+}$, and $I g f 1 r^{\Delta l o x /}$ genotypes (Figure 7c), indicating that the defective insulin secretion in $I g f 1 r^{\Delta l o x /-}$ mutants, which apparently leads to impairment of glucose tolerance, is not due to paucity of insulin. To assess whether the observed defect in insulin secretion could be corre- lated with $\beta$ cell structure abnormalities, we analyzed $\beta$ cells from $I g f 1 r^{\Delta l o x /}$ - mice and wild-type controls by electron microscopy. The results showed that there were no identifiable morphologic abnormalities in $\beta$ cells lacking IGF1R, except for a hypertrophic Golgi system, indicating that abnormal insulin secretion is not due to overt disruption of cellular architecture and failure to assemble insulin secretory granules (Figure 8).

Analysis of transcripts encoding proteins involved in exocytosis. Considering that the secretion data in isolated islets are consistent with a defect in insulin release, we analyzed the expression of several genes involved in insulin exocytosis using expression profiling with an oligonucleotide microarray. This analysis confirmed that Ifflr mRNA was decreased by approximately $80 \%$ in $I g f 1 r^{\Delta l o x /-}$ mice. However, the assay did not reveal differences in expression levels of several candidate genes, including those encoding the $\beta$-granule components synaptotagmin II and III, synaptobrevin 2 (VAMP-2), VAMP-3, and Rab-3a; the cytosolic proteins NSF, 14-3-3, Rab-3 GDI, Mss-4, Munc-18, and annexin II; the plasma membrane proteins SNAP-23, SNAP-25, syntaxin-1A, -3, -4A, -5A, -6 ; and the synaptic-like vesicles synaptophysin, synapsin I and II. Expression of the sulfonylurea receptor and calmodulin kinase II was also unaffected. Thus, the observed defect in insulin secretion is apparently not due to alterations in members of the insulin exocytotic pathway, at least at the transcriptional level.

\section{Discussion}

Type 2 diabetes results from combined abnormalities of $\beta$ cell function and insulin action. Although the exact nature of the $\beta$ cell defect remains elusive, one of the earliest demonstrable abnormalities in individuals at high risk of developing type 2 diabetes is an exaggerated insulin response to a glucose challenge, suggestive of an intrinsic secretory defect $(48,49)$. Moreover, unaffected first-degree relatives of type 2 diabetics exhibit abnor-

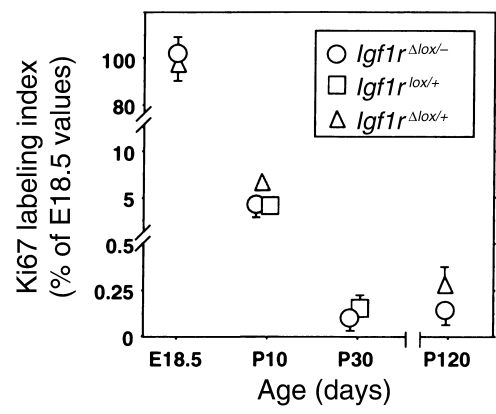

\section{Figure 6}

Developmental analysis of Ki67 labeling. A Ki67 labeling index was determined in mice of different ages by multiplying the mean number of Ki67/insulin double-positive cells per section by $\beta$ cell mass $(\mu \mathrm{g})$. The values at E18.5 were normalized to $100 \%$. None of the differences observed between the different genotypes are statistically significant. Two mice for each genotype were used at each time point, except for $\operatorname{lof} 1 r^{\operatorname{lox} /+}$ and $\lg f 1 r^{\Delta / \operatorname{lox} /+}$ at $\mathrm{P} 10$, where one mouse was used. Three to five sections per pancreas were scored as described in Methods. 

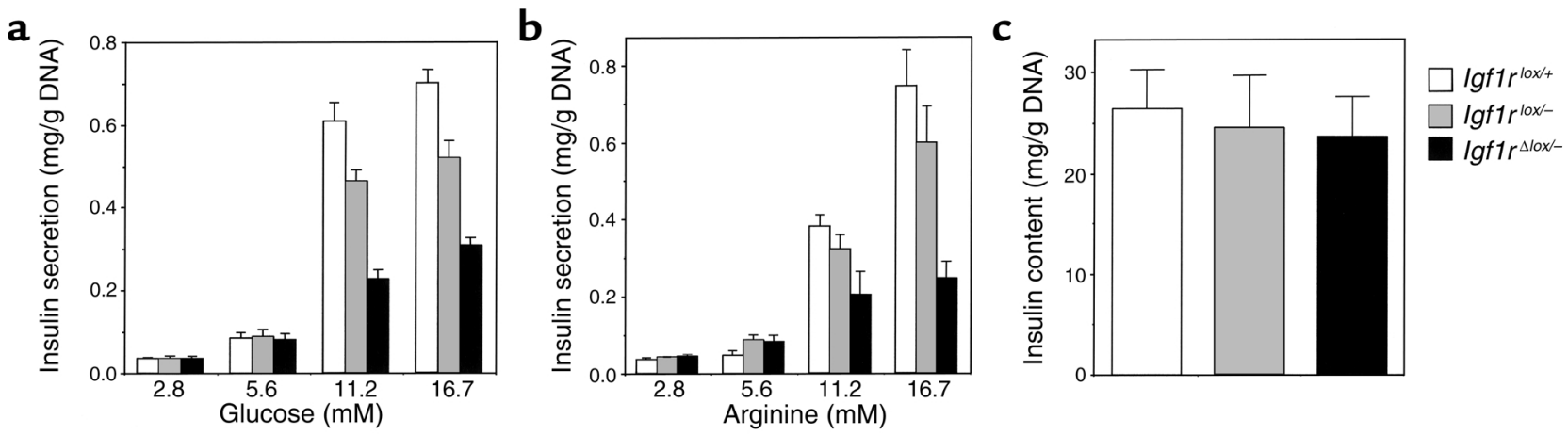

\section{Figure 7}

Insulin secretion and content in purified islets. Insulin release was determined in response to varying glucose (a) and arginine (b) concentrations. For each glucose concentration, ten islets derived from two or three mice of each genotype were used. Three separate experiments were performed and the results were averaged. (c) Insulin content in islets of the indicated genotypes was measured by high-salt buffer extraction followed by radioimmunoassay.

malities of the first-phase insulin response to glucose, similar to the defect observed in patients with active disease (50). Notably, $\beta$ cell secretory defects are exemplified by maturity onset diabetes of the young $(51,52)$, a genetically heterogeneous, highly penetrant, monogenic form of diabetes caused by mutations in genes that couple glucose metabolism to insulin release (53).

In most type 2 diabetics, defective insulin secretion is compounded with peripheral insulin resistance in various tissues (54). Initially, in response to this resistance, there is a compensatory increase in $\beta$ cell mass to preserve adequate insulin production. Over time, however, this compensation cannot be sustained. The mechanism of this response and the pathophysiology of its failure in type 2 diabetes remain unclear, but there is some evidence for circulating factors affecting islet proliferation (55). Alternatively, transient oscillations in glucose levels, occurring before the onset of overt hyperglycemia, may be sufficient to promote $\beta$ cell growth (56), or glucose may have a permissive effect in stimulating $\beta$ cell proliferation acting in concert with growth factors (12).

The observations that mice lacking IRS-1 develop defective insulin secretion, whereas mice lacking IRS-2 develop impaired $\beta$ cell proliferation, have raised the question of whether insulin signaling on one hand and IGF signaling on the other serve overlapping or distinct functions related to these phenotypic manifestations (57). In this regard, conditional ablation of $I r$ in $\beta$ cells results in a secretory defect similar to that observed in type 2 diabetes (25), but less severe than that observed in IRS-1-deficient $\beta$ cells (26). Insulin acting through IR appears to be required for regula- tion of its own synthesis and secretion (17), while the IGFs have been proposed to be involved in the promotion of $\beta$ cell proliferation, based on the observation that IgfIr haploinsufficiency increases the severity of diabetes in mice lacking IRS-2 (13). While our data do not support this view, there are potential explanations for the discrepancy between our observations and those in Irs $2^{-/-} I g f 1 r^{+/-}$mice. First, the tissue-specific phenotype that we describe here is not necessarily directly comparable with the state of ubiquitous haploinsufficiency in $I g \mathrm{fl}^{+/-}$heterozygotes carrying a null allele. Second, it is possible that IRS-2, in addition to mediating IGF signaling, mediates signaling by other growth factors, potentially acting in a strain-dependent manner. Finally, it remains to be seen whether IR could play a compensatory role in $\beta$ cell proliferation in the absence of IGF1R, as suggested by the observation that not only Igf1r haploinsufficiency, but also Ir haploinsufficiency results in accelerated $\beta$ cell failure in Irs $2^{-/-}$
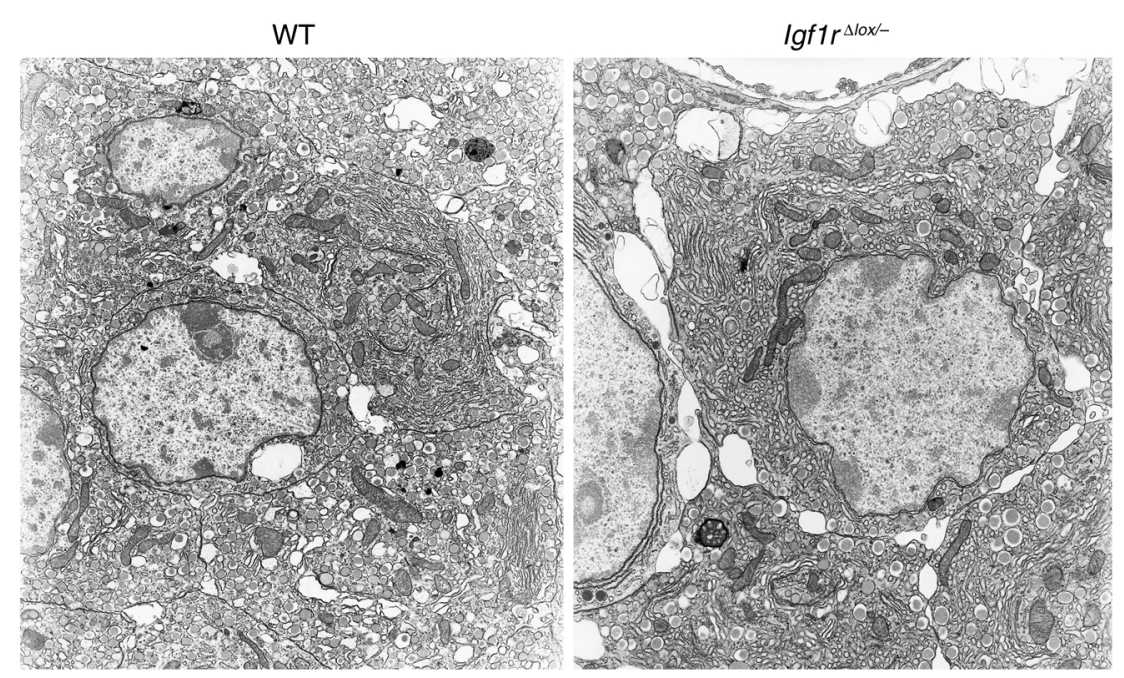

\section{Figure 8}

Electron microscopy of $\beta$ cells. Representative images of $\beta$ cells in wild-type and mutant mice are shown at $\times 11,300$ magnification. 
mice (58). Combined ablation of both the Ir and Igfir functions in $\beta$ cells is required to address this question. In contrast to the absence of a proliferative defect, $\beta$ cells lacking IGF1R exhibit a profound decrease of insulin secretion in response to both glucose and arginine. This impairment is reminiscent of the secretory defect observed in $\operatorname{Irs} 1^{-1-} \beta$ cells (26). Although the decrease in glucose-induced insulin secretion could be accounted for partly by the observed decrease in GLUT-2 expression, the inability of IGF1R-deficient $\beta$ cells to respond to arginine suggests that the defect lies in the exocytotic pathway. Since arginine promotes insulin release through direct membrane depolarization and $\mathrm{Ca}^{2+}$ influx $(59,60)$, our data indicate that IGF1R signaling could be involved in regulating insulin secretion at a step distal to that of ATP production and closure of ATP-sensitive K channels (61). These findings are consistent with the observation that insulin stimulates exocytosis through changes in intracellular $\mathrm{Ca}^{2+}$ stores in a PI 3-kinase-dependent fashion (19). In this regard, it is important to note that while some steps of the exocytotic process are stimulated by insulin signaling, others may be inhibited. It was shown, for example, that intracellular translocation of storage granules into the early releasable pool is inhibited by PI 3-kinase activation (27). By analogy, it can be hypothesized that the early stimulatory effect of IGF- 1 on insulin secretion in cultured $\beta$ cells, which is followed by a late phase of inhibition (62), is due to activation of different steps in the exocytotic process. Expression profiling using microarray analysis showed that there are no detectable differences in the transcription of known genes involved in insulin exocytosis. However, IGF1R signaling could promote this process by several additional mechanisms. For example, IGF1 may directly stimulate $\mathrm{Ca}^{2+}$ entry into $\beta$ cells, occurring through translocation of a recently described growth factor-regulated calcium-permeable channel belonging to the TRP family (63). Consistent with this hypothesis, there are reports suggesting that IGF- 2 promotes exocytosis in $\beta$ cells (64), while tyrosine kinase inhibitors apparently prevent insulin secretion in response to several secretagogues (18). Alternatively, IGF signaling may activate ATP-sensitive $\mathrm{K}$ channels in a PI 3-kinase-dependent manner, as already shown for insulin (15), or could impinge upon G protein-mediated exocytotic steps through one of the insulin/IGFsensitive $G$ protein subunits (65). Finally, an intriguing possibility is that IGFs regulate insulin secretion through an autocrine mechanism. This hypothesis has emerged from studies of mice lacking HNF-1 $\alpha$ (the MODY3 gene homologue) or overexpressing dominant negative mutant forms of HNF- $1 \alpha$ in $\beta$ cells (66-68), which develop a defect similar to that described here for $\beta$ cell-specific Igflr knockouts. Interestingly, IGF-1 appears to be an HNF- $1 \alpha$ target gene in $\beta$ cells that is downregulated in mice expressing a dominant negative HNF-1 $\alpha$ (69). Furthermore, the hypothesis mentioned above could explain why overexpression of another
IGF1R ligand, IGF-2, in $\beta$ cells of transgenic mice results in increased insulin secretion (38).

While this manuscript was under review, Kulkarni et al., using different strains of Cre-producing and Creresponding mice, reported the generation of mice lacking IGF1R in $\beta$ cells (70). Their findings are in agreement with ours, except that they did not study the response of purified islets to arginine, but reported normal arginine-induced insulin secretion in vivo. Interestingly, both we and Kulkarni report an increase in basal insulin values, although in our study the values did not reach statistical significance.

The similarities between the phenotype described here and those of Ir and Irs 1 knockouts indicate that IGF1R could have overlapping functions with those of Ir and could be signaling through IRS- 1 in $\beta$ cells. The identification of IGF-1-dependent mechanisms of exocytosis potentially could provide novel targets for therapeutic intervention in $\beta$ cell dysfunction.

\section{Acknowlegments}

This work was supported by Juvenile Diabetes Research Foundation grant 2000-893 to D. Accili and A. Efstratiadis. We thank members of the Accili and Efstratiadis laboratories for helpful discussions.

1. Matschinsky, F.M. 1996. Banting Lecture 1995. A lesson in metabolic regulation inspired by the glucokinase glucose sensor paradigm. Diabetes. 45:223-241.

2. Bonner-Weir, S. 1994. Regulation of pancreatic beta-cell mass in vivo. Recent Prog. Horm. Res. 49:91-104.

3. Bonner-Weir, S. 2000. Life and death of the pancreatic beta cells. Trends Endocrinol. Metab. 11:375-378.

4. Shaw, J., and Latimer, E. 1925. Regeneration of pancreatic tissue from the transplanted pancreatic duct in the dog. Am. J. Physiol. 76:49-53.

5. Bendayan, M. 1987. Presence of endocrine cells in pancreatic ducts. Pancreas. 2:393-397.

6. Bertelli, E., Regoli, M., Orazioli, D., and Bendayan, M. 2001. Association between islets of Langerhans and pancreatic ductal system in adult rat. Where endocrine and exocrine meet together? Diabetologia. 44:575-584.

7. Bonner-Weir, S., et al. 2000. In vitro cultivation of human islets from expanded ductal tissue. Proc. Natl. Acad. Sci. USA. 97:7999-8004.

8. Bouwens, L., and Pipeleers, D.G. 1998. Extra-insular beta cells associated with ductules are frequent in adult human pancreas. Diabetologia. 41:629-633.

9. Hart, A.W., Baeza, N., Apelqvist, A., and Edlund, H. 2000. Attenuation of FGF signalling in mouse beta-cells leads to diabetes. Nature. 408:864-868.

10. Garcia-Ocana, et al. 2000. Hepatocyte growth factor overexpression in the islet of transgenic mice increases beta cell proliferation, enhances islet mass, and induces mild hypoglycemia. J. Biol. Chem. 275:1226-1232.

11. Vasavada, R.C., et al. 2000. Targeted expression of placental lactogen in the beta cells of transgenic mice results in beta cell proliferation, islet mass augmentation, and hypoglycemia. J. Biol. Chem. 275:15399-15406.

12. Rhodes, C.J. 2000. IGF-I and GH post-receptor signaling mechanisms for pancreatic beta-cell replication. J. Mol. Endocrinol. 24:303-311.

13. Withers, D.J., et al. 1999. Irs- 2 coordinates Igf- 1 receptor-mediated betacell development and peripheral insulin signalling. Nat. Genet. 23:32-40.

14. Hugl, S.R., White, M.F., and Rhodes, C.J. 1998. Insulin-like growth factor I (IGF-I)-stimulated pancreatic beta-cell growth is glucose-dependent. Synergistic activation of insulin receptor substrate-mediated signal transduction pathways by glucose and IGF-I in INS-1 cells. J. Biol. Chem. 273:17771-17779.

15. Khan, F.A., Goforth, P.B., Zhang, M., and Satin, L.S. 2001. Insulin activates ATP-sensitive $\mathrm{K}(+)$ channels in pancreatic beta-cells through a phosphatidylinositol 3-kinase-dependent pathway. Diabetes. 50:2192-2198.

16. Leibiger, I.B., Leibiger, B., Moede, T., and Berggren, P.O. 1998. Exocytosis of insulin promotes insulin gene transcription via the insulin receptor/PI 3-kinase/p70 s6 kinase and CaM kinase pathways. Mol. Cell. 1:933-938.

17. Leibiger, B., et al. 2001. Selective insulin signaling through a and b insulin receptors regulates transcription of insulin and glucokinase 
genes in pancreatic beta cells. Mol. Cell. 7:559-570.

18. Persaud, S.J., Harris, T.E., Burns, C.J., and Jones, P.M. 1999. Tyrosine kinases play a permissive role in glucose-induced insulin secretion from adult rat islets. J. Mol. Endocrinol. 22:19-28.

19. Aspinwall, C.A., et al. 2000. Roles of insulin receptor substrate-1, phosphatidylinositol 3-kinase, and release of intracellular Ca2+ stores in insulin-stimulated insulin secretion in beta-cells. J. Biol. Chem. 275:22331-22338.

20. Withers, D.J., et al. 1998. Disruption of IRS-2 causes type 2 diabetes in mice. Nature. 391:900-904.

21. Kubota, N., et al. 2000. Disruption of insulin receptor substrate 2 causes type 2 diabetes because of liver insulin resistance and lack of compensatory beta-cell hyperplasia. Diabetes. 49:1880-1889.

22. Pende, M., et al. 2000. Hypoinsulinaemia, glucose intolerance and diminished beta-cell size in S6K1-deficient mice. Nature. 408:994-997.

23. Tuttle, R.L., et al. 2001. Regulation of pancreatic beta-cell growth and survival by the serine/threonine protein kinase Akt1/PKBalpha. Nat. Med. 7:1133-1137.

24. Bernal-Mizrachi, E., Wen, W., Stahlhut, S., Welling, C., and Permutt, M 2001. Transgenic mice expressing a constitutively active Akt $1 / \mathrm{PKB} \alpha$ in pancreatic islet $\beta$-cells exhibit striking hypertrophy, hyperplasia and hyperinsulinemia. J. Clin. Invest. 108:1631-1638.

25. Kulkarni, R.N., et al. 1999. Tissue-specific knockout of the insulin receptor in pancreatic beta cells creates an insulin secretory defect similar to that in type 2 diabetes. Cell. 96:329-339.

26. Kulkarni, R.N., et al. 1999. Altered function of insulin receptor substrate1-deficient mouse islets and cultured beta-cell lines. J. Clin. Invest. 104:R69-R75.

27. Eto, K., et al. 2002. Phosphatidylinositol 3-kinase suppresses glucosestimulated insulin secretion by affecting post-cytosolic $[\mathrm{Ca}(2+)]$ elevation signals. Diabetes. 51:87-97.

28. Zawalich, W.S., and Zawalich, K.C. 2000. A link between insulin resistance and hyperinsulinemia: inhibitors of phosphatidylinositol 3-kinase augment glucose-induced insulin secretion from islets of lean, but not obese, rats. Endocrinology. 141:3287-3295.

29.Zhang, Q., Berggren, P.O., Larsson, O., Hall, K., and Tally, M. 1998. Insulin-like growth factor II inhibits glucose-induced insulin exocytosis. Biochem. Biophys. Res. Commun. 243:117-121.

30.Zhao, A.Z., Zhao, H., Teague, J., Fujimoto, W., and Beavo, J.A. 1997. Attenuation of insulin secretion by insulin-like growth factor 1 is mediated through activation of phosphodiesterase 3B. Proc. Natl. Acad. Sci. USA. 94:3223-3228.

31. Leahy, J.L., and Vandekerkhove, K.M. 1990. Insulin-like growth factor-I at physiological concentrations is a potent inhibitor of insulin secretion. Endocrinology. 126:1593-1598.

32. Petrik, J., et al. 1999. A low protein diet alters the balance of islet cell replication and apoptosis in the fetal and neonatal rat and is associated with a reduced pancreatic expression of insulin-like growth factor-II. Endocrinology. 140:4861-4873.

33. Hill, D.J., Hogg, J., Petrik, J., Arany, E., and Han, V.K. 1999. Cellular distribution and ontogeny of insulin-like growth factors (IGFs) and IGF binding protein messenger RNAs and peptides in developing rat pancreas. J. Endocrinol. 160:305-317.

34. Hoog, A., et al. 1996. Increased amounts of a high molecular weight insulin-like growth factor II (IGF-II) peptide and IGF-II messenger ribonucleic acid in pancreatic islets of diabetic Goto-Kakizaki rats. Endocrinology. 137:2415-2423.

35. Portela-Gomes, G.M., and Hoog, A. 2000. Insulin-like growth factor II in human fetal pancreas and its co-localization with the major islet hormones: comparison with adult pancreas. J. Endocrinol. 165:245-251.

36. Scaglia, L., Cahill, C.J., Finegood, D.T., and Bonner-Weir, S. 1997. Apoptosis participates in the remodeling of the endocrine pancreas in the neonatal rat. Endocrinology. 138:1736-1741.

37. Petrik, J., Arany, E., McDonald, T.J., and Hill, D.J. 1998. Apoptosis in the pancreatic islet cells of the neonatal rat is associated with a reduced expression of insulin-like growth factor II that may act as a survival factor. Endocrinology. 139:2994-3004.

38. Devedjian, J.C., et al. 2000. Transgenic mice overexpressing insulin-like growth factor-II in beta cells develop type 2 diabetes. J. Clin. Invest. 105:731-740.

39. Rossetti, L., et al. 1996. Hepatic overexpression of insulin-like growth factor-II in adulthood increases basal and insulin-stimulated glucose disposal in conscious mice. J. Biol. Chem. 271:203-208.

40. Petrik, J., et al. 1999. Overexpression of insulin-like growth factor-II in transgenic mice is associated with pancreatic islet cell hyperplasia. Endocrinology. 140:2353-2363.

41. Liu, J.P., Baker, J., Perkins, A.S., Robertson, E.J., and Efstratiadis, A. 1993. Mice carrying null mutations of the genes encoding insulin-like growth factor I (Igf-1) and type 1 IGF receptor (Igf1r). Cell. 75:59-72.

42. Dietrich, P., Dragatsis, I., Xuan, S., Zeitlin, S., and Efstratiadis, A. 2000. Conditional mutagenesis in mice with heat shock promoter- driven cre transgenes. Mamm. Genome. 11:196-205.

43. Herrera, P.L. 2000. Adult insulin- and glucagon-producing cells differentiate from two independent cell lineages. Development. 127:2317-2322.

44. Di Cola, G., Cool, M.H., and Accili, D. 1997. Hypoglycemic effect of insulin-like growth factor-1 in mice lacking insulin receptors. J. Clin. Invest. 99:2538-2544.

45. Kido, Y., et al. 2000. Tissue-specific insulin resistance in mice with combined mutations of insulin receptor, IRS-1 and IRS-2. J. Clin. Invest. 105:199-205.

46. Kitamura, T., et al. 2001. Preserved pancreatic beta-cell development and function in mice lacking the insulin receptor-related receptor. Mol. Cell. Biol. 21:5624-5630.

47. Klein, U., et al. 2001. Gene expression profiling of B cell chronic lymphocytic leukemia reveals a homogeneous phenotype related to memory B cells. J. Exp. Med. 194:1625-1638.

48. Aronoff, S.L., Bennett, P.H., Gorden, P., Rushforth, N., and Miller, M. 1977. Unexplained hyperinsulinemia in normal and "prediabetic" Pima Indians compared with normal Caucasians. An example of racial differences in insulin secretion. Diabetes. 26:827-840.

49. Lillioja, S., et al. 1991. Exaggerated early insulin release and insulin resistance in a diabetes-prone population: a metabolic comparison of Pima Indians and Caucasians. J. Clin. Endocrinol. Metab. 73:866-876.

50. O'Rahilly, S., Turner, R.C., and Matthews, D.R. 1988. Impaired pulsatile secretion of insulin in relatives of patients with non-insulin-dependent diabetes. N. Engl. J. Med. 318:1225-1230.

51. Herman, W.H., et al. 1994. Abnormal insulin secretion, not insulin resistance, is the genetic or primary defect of MODY in the RW pedigree. Diabetes. 43:40-46.

52. Byrne, M.M., et al. 1996. Altered insulin secretory responses to glucose in diabetic and nondiabetic subjects with mutations in the diabetes susceptibility gene MODY3 on chromosome 12. Diabetes. 45:1503-1510.

53. Bell, G.I., and Polonsky, K.S. 2001. Diabetes mellitus and genetically programmed defects in beta-cell function. Nature. 414:788-791.

54. Accili, D., Kido, Y., Nakae, J., Lauro, D., and Park, B.-C. 2001. Genetics of type 2 diabetes: insights from targeted mouse mutants. Curr. Mol. Med. 1:9-23.

55. Flier, S.N., Kulkarni, R.N., and Kahn, C.R. 2001. Evidence for a circulating islet cell growth factor in insulin-resistant states. Proc. Natl. Acad. Sci. USA. 98:7475-7480.

56. Bonner-Weir, S. 2000. Perspective: postnatal pancreatic beta cell growth. Endocrinology. 141:1926-1929.

57. Accili, D. 2001. A kinase in the life of the beta cell. J. Clin. Invest. 108:1575-1576

58. Kitamura, T., et al. 2001. The transcription factor FKHR regulates pancreatic beta cell survival. Diabetes. 50(Suppl. 2):A345.

59. Henquin, J. 1992. The biophysical events involved in the stimulation of insulin release by arginine. In Guanidino compounds in biology and medicine. P. DeDeyen, B. Marescau, V. Stalon, and I. Qureshi, editors. John Wiley $\&$ Co. New York, New York, USA. 109-116.

60. Charles, S., Tamagawa, T., and Henquin, J.C. 1982. A single mechanism for the stimulation of insulin release and $86 \mathrm{Rb}+$ efflux from rat islets by cationic amino acids. Biochem. J. 208:301-308.

61. Henquin, J.C. 2000. Triggering and amplifying pathways of regulation of insulin secretion by glucose. Diabetes. 49:1751-1760.

62. Hill, D.J., Sedran, R.J., Brenner, S.L., and McDonald, T.J. 1997. IGF-I has a dual effect on insulin release from isolated, perifused adult rat islets of Langerhans. J. Endocrinol. 153:15-25

63. Kanzaki, M., et al. 1999. Translocation of a calcium-permeable cation channel induced by insulin-like growth factor-I. Nat. Cell Biol. 1:165-170.

64. Zhang, Q., et al. 1997. Insulin-like growth factor II signaling through the insulin-like growth factor II/mannose-6-phosphate receptor promotes exocytosis in insulin-secreting cells. Proc. Natl. Acad. Sci. USA. 94:6232-6237.

65. Lang, J. 1999. Molecular mechanisms and regulation of insulin exocytosis as a paradigm of endocrine secretion. Eur. J. Biochem. 259:3-17.

66. Hagenfeldt-Johansson, K.A., et al. 2001. Beta-cell-targeted expression of a dominant-negative hepatocyte nuclear factor- 1 alpha induces a maturity-onset diabetes of the young (MODY)3-like phenotype in transgenic mice. Endocrinology. 142:5311-5320.

67. Yamagata, K., et al. 2002. Overexpression of dominant-negative mutant hepatocyte nuclear factor-1alpha in pancreatic beta-cells causes abnormal islet architecture with decreased expression of E-Cadherin, reduced beta-cell proliferation, and diabetes. Diabetes. 51:114-123.

68. Pontoglio, M., et al. 1998. Defective insulin secretion in hepatocyte nuclear factor 1alpha-deficient mice. J. Clin. Invest. 101:2215-2222.

69. Yang, Q., et al. 2002. Hepatocyte nuclear factor-1alpha modulates pancreatic beta-cell growth by regulating the expression of insulin-like growth factor-1 in INS-1 cells. Diabetes. 51:1785-1792.

70. Kulkarni, R.N., et al. 2002. Beta-cell-specific deletion of the Igf1 receptor leads to hyperinsulinemia and glucose intolerance but does not alter beta-cell mass. Nat. Genet. 31:111-115. 